
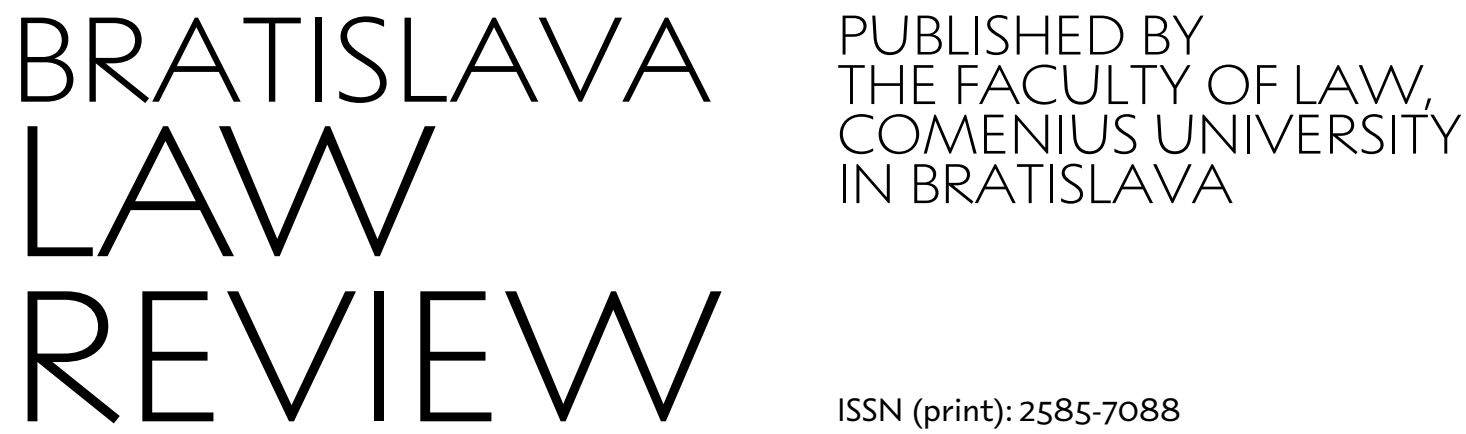

ISSN (print): $2585-7088$

ISSN (electronic): 2644-6359

\title{
MANDATORY AND DEFAULT RULES IN SERBIAN COMPANY LAW / Branislav Malagurski
}

\author{
Prof. dr Branislav Malagurski \\ Business Academy in Novi Sad, \\ Faculty of European Legal and Political \\ Studies; Narodnog fronta 53, \\ 21000, Novi Sad; Serbia \\ bmalagurski@yahoo.com \\ ORCID:0000-0003-1875-8090
}

\begin{abstract}
The matter of company law in Serbia is regulated by the Law on Companies, which, unlike the Law on Obligations, does not contain a general provision defining whether it is based on the freedom of will. Therefore, it can be concluded that the rules of the Law on Companies are mandatory in general. Such a conclusion only confirms an exceptionary provision in its part regulating limited liability companies, which defines that founders of a limited liability company can regulate their mutual relations and their relations with the Company on a free basis, unless it is otherwise defined by this Law. So, only the rules regulating mutual relations of founders and their relations with the limited liability company, are default in general, unless otherwise provided in a particular case. Other rules of the company law in Serbia, including those related to joint-stock companies, are mandatory in general. However, even when the provisions regulating certain matters are mandatory, it does not mean that there is absolutely no space for deviations, i. e. an expression of company founders' will, like in the cases of special duties described below; or in cases where founders can choose between offered mandatory alternatives (selecting bodies to govern the company); or, in a case if the founder's consent is needed when diminishing his rights; or when special rights of dissenting shareholders are introduced. The deviations from the mandatory rule in such cases do not necessarily mean that the rule has become a default one.
\end{abstract}

Key words: default rules, mandatory rules, Serbian company law, Serbian law

\section{Suggested citation:}

Malagurski, B. (2020). Mandatory and Default Rules in Serbian Company Law. Bratislava Law Review, 4(1), 79-92.

https://doi.org/10.46282/blr.2020.4.1.172
Accepted: 15 June 2020

Published: 31 August 2020

\section{INTRODUCTION: CONCEPT OF AUTONOMY OF WILL IN SERBIAN CIVIL AND COMPANY LAW}

In Serbian positive law, there is no Civil Code $^{1}$ or a Commercial Code as such. Currently, the key laws regulating civil and commercial matters are the Law on

\footnotetext{
1 Serbia had enacted the Civil Code in $19^{\text {th }}$ Century (The Civil Code for the Kingdom of Serbia, text as of 11 March 1844), however, only some of its rules, in case of legal gap, are still applicable nowadays. Serbia has opted to implement in that matter the laws of former SFRY, whose system was based on Swiss concept not to have a civil code, but to have separate law on obligations and laws regulating other civil law matters.
} 
Obligations ${ }^{2}$ and the Law on Companies. ${ }^{3}$ The first of them regulates contracts (of civil and trade law). The second one regulates legal persons that participate in commercial transactions, having the status of merchants. Thereby, this law regulates limited liability companies, joint-stock companies, general and limited partnerships, as well as entrepreneurs.

It is indisputable that the freedom of concluding a contract is a principle of Serbian contract law according to the Law on Obligations - in its art. 10. The question may be raised whether it is also a constitutional principle. In Vladimir Vodinelić's opinion, the autonomy of the will is guaranteed within the framework of the guarantee of freedom of a person's development proclaimed in art. 23, paragraph 2 of the Constitution of Serbia (2012, p. 86). Therefore, it can be expected that the LoO is also based on the principle of autonomy of the free will of the respective parties. Further, it will be discussed whether this principle is transferred to the entities that are holders of the rights and obligations in trade.

According to the provision of art. 10 of the LoO, the parties to the obligations are free within the bounds of compulsory regulations, public order and good customs to regulate their relations at will. The article does not specifically regulate contracts on the foundation of legal persons. In order to better specify the scope of this article, it is necessary to recall that the contract autonomy is manifested in the contract law through three major principles: the freedom to contract, the principle of binding contract strength, and the principle of the relative effect of the contract (Đurđević \& Pavić, 2016, pp. 4647). ${ }^{4}$

In addition to these provisions, in art. 20, titled "The dispositive character of the provisions of the law", the LoO determines that its provisions are default in principle, which means that the parties to the contract may regulate them differently than provided by the LoO. However, in the same article, the LoO stipulates that the contracting parties do not have a possibility to regulate the relationship differently when: 1) it follows a particular provision of the law; or 2) it is derived from the general meaning of that particular provision. In other words, in such cases the particular provision is mandatory. The parties cannot exclude its application by contract and regulate their relationship differently (Đurđević \& Pavić, 2016, p. 49).

Hence, the freedom to contract is the general principle of the contract law and it is an abstract. It involves only the basic option whether or not to contract. In other words, it is the freedom of contractors to regulate the content of their contract by their own free will. The LoO classified the disposition of the subjects as a principle and gave it perhaps too broad marginal title - Autonomy of Will (Antić, 2013, p. 6).

The situation is not expected to be changed after a Draft Serbian Civil Code enters into force. As for the obligations, it is defined that: "Parties can regulate their obligations otherwise than defined by this Law, if not followed otherwise according to particular legal

\footnotetext{
2 Law on Obligations, Official Journal of the SFRY no. 29/78, 39/85, 45/89 and 57/89, Official Journal of the FRY no. 31/93 and Official Journal of Serbia and Montenegro no. 1/2003 - Constitutional Charter and Official Journal of Serbia no. 18/2020 (hereinafter "LoO").

3 Law on Companies, Official Gazette of Republic of Serbia no. 36/2011, 99/2011, 83/2014, 5/2015, 44/2018, 95/2018 and 91/2019, hereinafter "LoC".

4 The principle of relative effect, i.e. that "contract creates rights and obligations for contracting parties" is established in art. 148 of the LoO, while the principle that the contract has binding force "binds the parties as a law" is defined in art. 17 of the LoO. According to that, the parties are in a contractual relationship, regardless of the source from which it comes out. They are obliged to execute the obligation and they are responsible in case of their failure with the execution. However, the freedom to contract means also that the content of the agreement is limited by mandatory regulations, as well as by public order and customs, terms introduced in the LoO by the Law on Amendments to the Obligations Act of 1993.
} 
provision, or its sense". In addition to this, it is provided that: "Contractual parties are free, in frames of the mandatory rules, the public order, and good customs, to regulate their relationship according to their own will. The mandatory provisions referring to the content of particular contracts are an integral part of these contracts, complement them or take place of the contractual provisions, which do not comply with them". ${ }^{6}$ As related to its subjects, i.e. the persons of civil law, it is determined that: "The civil rights subjects are free to regulate their relations according to their own will, within the limits of the mandatory rules, the public order and good customs". ${ }^{7}$ Therefore, the principle of the autonomy of will is to be applied to the subjects of civil law in the matter regulating their relations. The impact of this provision to the subjects of trade law (including companies) is yet to be evaluated.

This work is further focused to the situation with default and mandatory provisions of the company law in Serbia.

\section{MANDATORY AND DEFAULT PROVISIONS OF THE LAW ON COMPANIES}

As for the legislation which defines legal subjects that are active in trade and regulates their relation to contracts, the Serbian Law on Companies does not contain a general provision defining whether its provisions are default or mandatory. Instead of that, it starts with the provision that "this Law regulates the legal position of companies and other forms of organization in accordance with this Law, in particular their establishment, management, status changes, changes in legal form, dissolution and other issues relevant to their status, as well as the legal position of entrepreneurs". Having in mind the content of this provision, it is possible to conclude that, the provisions of this law are prevailingly mandatory, as: 1. the law regulates the legal position of companies, i. e. contains precise determinants of a company; and 2. it regulates the status matters of a company in Serbia (the prerequisites for its foundation and particular acting, its bodies and management, status changes, the conditions for its dissolution etc.), which all need to be defined without a possibility to change the provision of the law by the will of company's founders, employees, business partners, creditors, etc. The view that the provisions of the corporate law are mandatory can be found in the Serbian literature, too. One of the key authors says, that in the area of corporate law, especially in the domain of a joint-stock company and a limited liability company, the imperative norms dominate (ius imperium, ius cogens) (Vasiljević, 2017, p. 299).

However, it does not mean that all provisions of the Law on Companies (hereinafter as LoC) are mandatory. In particular, the companies as legal persons conducting business should have certain degree of discretion and autonomy in arranging their affairs, i.e. adjusting the norms to their specific needs.

2.1. Does the Academic Discourse and Jurisprudence on the Issue Reflect on the Function of Company Law or of the Specific Rule when Deciding Whether it is Mandatory?

When deciding whether the particular rules of the company law in Serbia should be default or mandatory, the focus is laid more on the specific rules and interest being under its protection, than on the function of company law. In the Serbian company law

\footnotetext{
${ }^{5}$ Art. 160 of the Draft Serbian Civil Code, as of 285 2019, (hereinafter "Draft Serbian Civil Code").

${ }^{6}$ Art. 164 of the Draft Serbian Civil Code.

${ }^{7}$ Art. 6 of the Draft Serbian Civil Code.

8 Art. 1 of the Law on Companies, Official Gazette of Republic of Serbia no. 36/2011, 99/2011, 83/2014,

5/2015, 44/2018, 95/2018 and 91/2019).
} 
there is no general provision defining which matter is regulated by the default and which by the mandatory rules. Moreover, since the autonomy of will is not explicitly set as the principle in the LoC, it can be concluded that the mandatory provisions dominate in this matter. In particular, this law regulates the matters of status of companies, such as the prerequisites for foundation of companies, creation and functioning of its bodies, the minimum conditions to act in a particular way, the conditions of its dissolution, etc.

\subsection{General Rule in the Matter of Relations of Founders and Limited Liability Company}

For some matters, even in LoC, the "dispositive nature" of the rule is expressively determined. That is the case, for example, with the art. 140 LoC, which states that founders of a limited liability company (hereinafter as "LLC") define their mutual relations, as well as their relations with the Company freely, unless it is otherwise defined by this Law. This provision is of general nature for the relations between founders of an LLC, as well as for LLC's relations with its founders. This does not mean that the said rule (art. 140 ) is a general principle for everything concerning LLCs, i. e. all matters of the company law. That's because there are other matters beside the relations between a company and its founders, which are regulated by LoC (such as status matters, its bodies, minimum equity capital, transfer of shares, dissolution of company, etc). So, unlike being "silent" at the beginning, when it should have defined the rules for the overall company law (whether rules are default or mandatory), as far as an LLC is concerned, the LoC defines that the provisions which regulate the relations between founders, as well as their relations with LLC, are default "unless otherwise defined by this law". Therefore, a general rule for LLCs is that their rules are mandatory. But, the rules applying to the mutual relations of founders of an LLC and between an LLC and its founders, are default by an exception, unless otherwise defined (for particular cases). So, there is still one general rule in this matter.

In order to be able to define on your own the rules for relations between the founders of the LLC and their relations with the company, this principle is very important, almost crucial for arranging partnerships in an LLC, and it is of paramount importance when a business is run in a partnership between two or more legal and/or natural persons, giving an LLC a great advantage. This feature combined with low minimum capital requirements and the "privilege" of limited liability makes LLCs the most widely used form of a company in the Serbian economy. Specifically, the founders of LLCs regulate their mutual relations in LLCs, as well as their relations with those LLCs by their own will, unless stated otherwise by the LoC incertain situations. In spite of the overall mandatory character of the LoC, the rule in question means that almost every issue in an $L L C$ related to the relations between founders and an LLC is governed by the principle of the autonomy of will of LLC founders, with relatively few mandatory provisions. These provisions refer to the matters that cannot be put at founder's absolute discretion (to abuse their rights against minority shareholders, or to offend the public interest).

There is also an interesting issue, why the only rule of general nature defining the autonomy of will for the particular matter is incorporated in the part that relates to LLCs. Does it mean that shareholders of a joint-stock company (hereinafter as "JSC") cannot in general regulate mutual relations and their relations with a JSC at free will, or that they can do so upon the mutatis mutandis principle? Having in mind that the mandatory rules are regulating JSCs more stringently than LLCs, the conclusion might be rather that the autonomy of will can exceptionally regulate the relations between shareholders of a JSC, and between them and the company itself, too. But in general, the rules regulating the 
relations between shareholders and a JSC have mandatory character. So, the rule of art. 140 of LoC does not apply mutatis mutandis to JSCs (cf. Novaković, 2018, p. 129). ${ }^{9}$

It's a pity that the prominent commentaries of the Serbian LoC devote so little space to an important and unique art. 140 of LoC. One of them only paraphrases the article, adding that the will of founders is limited by mandatory rules. Thereby, this article gives them an opportunity to resolve some questions of functioning of an LLC in another way (for example, the division of profit disproportionately to the percentage of their shares), or certain questions of relations of founders and a company to be resolved differently to what LoC has defined (Stefanović \& Stanivuk, 2012, pp. 152-153). The other commentary, besides paraphrasing the same provision, only adds that it differs an LLC to a JSC, where mandatory provisions predominantly regulate the relations of shareholders (Novaković, 2018, p. 129). Even turning to the commentaries of the same provision, included in the former Law on Companies, does not help much (cf. Vasiljević, 2006, p. 251). ${ }^{10}$

\subsection{Rules for LLC Status and Other Matters}

In the basic status matters, without which the functioning and existence of LLCs would not be possible, though there is no explicit general rule, it is clear that the rules here are mandatory. Such cases refer to the mandatory minimum cash equity capital of LLCs, the type of deposits, the statutory bodies of LLCs and other similar issues, which are of a nature that they cannot be completely regulated at the discretion of the founders of LLCs. Therefore, the mandatory provisions become important where the status and organization of LLCs is concerned. But even then, these mandatory provisions leave room for founders to choose from several offered options. It would be absurd and lead to legal uncertainty if every LLC had its bodies set up and installed by each founder of a given LLC. Therefore, the provision on LLC bodies should be mandatory. However, even in such matters, the law provides for a number of exceptions that favour the freedom to contract. For example, the law stipulates that mandatory governing bodies of an LLC are either a board or a director, but still leaves the founders to decide for themselves whether they want the governing body to be a director or a board.

In addition, there is a number of matters and topics that cannot be observed as being at free disposition of the founders of an LLC. For example, a special regime for nullity in the company law rests on the increased need to protect security in legal transactions. A special protection of the stated interests through a specific concept of nullity of the company law goes hand in hand with the system of registration and publication of information on business entities, more precisely with the principles of publicity and trust in the registered and published data (Jevremović-Petrović, 2017, pp. 71-72). The nullity of the articles of association envisaged by the provisions of the LoC is the essence of the provisions on nullity (of founding) of company and their content is shaped to a large extent under the influence of the EU law, albeit with certain peculiarities,

\footnotetext{
9 Though not so clear in all commentaries on the art. 140 LoC, in certain Serbian literature, there still can be found a statement that the freedom to freely regulate mutual relations of founders and their relations with an LLC differs them from a JSC, where the law itself (mandatory provisions) predominantly regulates the relations of shareholders.

${ }^{10}$ Art. 105 of former Law on Companies (Official Gazette of Republic of Serbia no. 125/2004) had the same provision. The most prominent commentary of that Law, after paraphrasing the provision, only mentions the matters where mandatory provisions limit it, and then it is necessary to have articles of association, or the founders may have only a single share, or the founders are liable for their obligations, etc. (Vasiljević, 2006, p. 251).
} 
mostly in relation to the conceptual determination of nullity. Specifically, the Serbian law concentrated the regime of nullity of incorporation on the nullity of articles of association (Jevremović-Petrović, 2017, p. 75). The Serbian law regulates nullity of articles of association in two articles of the LoC, in which it specifies, the reasons for nullity in the first article, while in the second one it regulates the procedure for establishing nullity and its effect. ${ }^{11}$

An application of the institute of nullity in Serbian practice is not a last resort, but a regular mechanism for resolving numerous irregularities in the establishment of companies. This indicates weaknesses within the established control system. Therefore, the main task of the reform of company law in Serbia should be taking the changes in the existing system of control over the establishment of companies into account (Jevremović-Petrović, 2017, p. 93).$^{12}$ However, that would not impact these rules to remain mandatory ones.

The Serbian jurisprudence also confirmed that the rules defining the rights of LLC founders are mandatory ones. For example, as referred to the provision of art. 142 paragraph 2 part 1 of the LoC, the decision to amend the founding act that diminishes the rights of a founder of an LLC can only be made with a consent of the respective founder. ${ }^{13}$ Or, referring to the provision of art. 195 of the LoC, the decision of the general meeting of shareholders may exclude a member of the company only in case of nonpayment or not entering the contributions, and thus within a given timeframe or an extended deadline. ${ }^{14}$

\subsection{Rules for Shareholders' Relations and Their Relations with a JSC}

Though there is no explicit general default rule regulating relations of shareholders and JSCs, there are still bylaw provisions stating that shareholders may limit the right of any of shareholders, i.e. on their free will. Closer defined, LoC entitles shareholders to limit the right of a shareholder to personally participate in general meetings, if such a shareholder does not dispose with the minimum number of shares of particular class. This rule leaves space for the will of shareholders and it might be considered to be a default rule. However, even this mandatory rule nevertheless stipulates that the minimum number of shares of such a shareholder may not exceed $0.1 \%$ of shares of the class he disposes with (see Radovic, 2014, p. 71). ${ }^{15}$

When it comes to shareholders asking questions at a JSC general meeting, the literature provides comments on the boundaries of autonomous regulation in that matter, too. It is stated that these rules are of a mandatory character, to the extent in which a minimum degree of protection is guaranteed to those shareholders (see Radovic, 2014, p. 78). ${ }^{16}$ On the other hand, the same author emphasizes that the right of shareholders to ask questions during a JSC general meeting can also be extended to the time before the particular meeting, although the rule itself does not explicitly provide for it. Such provision

\footnotetext{
11 Arts. 13 and 14 LoC.

12 In addition, it would be desirable for the Serbian law to regulate the existing system of nullity more clearly. It should primarily be conceptually defined as the nullity of establishing a company. The nullity thus defined would have to cover all the defects in the creation of a company without limiting itself to either the legal basis (the founding act) or the registration process itself.

13 The Decision of the Commercial Court of Appeal, PZ 7243/13 (20 September 2013) Bilten sudske prakse Privrednih sudova (Practice of Commercial Courts Bulletin) 3/2015, p. 206.

14 Decision of the Commercial Court of Appeal, PZ 541/13 (24 January 2013 Bilten sudske prakse Privrednih sudova (Practice of Commercial Courts Bulletin) 4/2013, p. 90.

15 See also art. 328 para. 3 LoC.

16 See also art. 335 para. 2 pt. 1 in connection with art. 335 para. 1 pt. 7 LoC.
} 
is named as a relative imperative rule, where shareholders can otherwise agree on more strict solution compared to the one defined by the law (Radović, 2010, p. 118). This attitude is justified, if it is kept in mind that the limits of this mandatory rule create a minimum degree of protection that should be provided to each shareholder.

The whole cluster of mandatory rules of the LoC relates to the protection of rights of minority shareholders. The principle of having mandatory rules in regulation of JSCs is in particular applicable to the protection of the rights of minority shareholders, because if these norms were default, the shareholders would need to rely on general company acts enacted by majority shareholders, which would jeopardize their position (Novičić, 2012, p. 115). This protection of minority rights includes: the right of minority shareholders to request a court in a non-contentious procedure to order holding of a regular session of the general meeting; the right of personal participation of minority shareholders in the work of the general meeting as an important right in the exercise of voting rights; the right of minority shareholders to propose amendments to the agenda (Novičić, 2012, p. 116); ${ }^{17}$ the right of minority shareholders to access acts and documents of the particular company (Novičić, 2012, p. 117): ${ }^{18}$ the rights of minority shareholders to withdraw from the company. The latter right is exercised in several ways: through the right of dissenting shareholders, the right to sell shares to the majority shareholder, and the forced purchase of shares (Novičić, 2012, pp. 118-119). ${ }^{19}$

From the point of view of mandatory or default rules, the matter of dissenting shareholder in a JSC is very interesting. ${ }^{20}$ The special rights of dissenting shareholders can be defined as the right of any shareholder who does not agree with the decision that was brought at the general meeting by shareholders to ask his shares to be purchased by the JSC. And thus under the condition that there will be a fundamental change in the company control. ${ }^{21}$ However, starting from the general rule which defines that

\footnotetext{
17 The provision of art. 372 LoC stipulates that one or more shareholders holding at least $5 \%$ of voting shares may propose additional agenda items (without limitation of number) to the board of directors or the supervisory board for the meeting of the company for discussion and decision-making at the general meeting of the company, with the proposal of decisions and the explanation of the proposal.

18 The law accepts the principle of the First Directive of the European Union on the transparency of operations of a JSC. The provision of art. 81 LoC gives the right of access to the acts and documents of the company to each shareholder, regardless of the amount of the share capital he holds, provided that he requests in writing from the company the access to the acts and documents of the company, and is obliged to make the request in the manner prescribed by the above provision to indicate the purpose for which he or she is seeking access to the acts and documents of the company, as well as to provide the JSC with information on the third parties to whom he or she intends to communicate the document, the act or information to which he or she accesses. 19 The dissenting shareholders are the shareholders who voted against or abstained from voting in favour of the decision or were not present at the general meeting at which the issues referred to in art. 474 para. 1 pt. 1-7 Companies Act. The way of exit of shareholders can also be executed by forced purchase of shares, which implies the right of a majority shareholder to provide the general meeting with a proposal of a decision on the forced purchase of all shares with payment. Accordingly, the right of a minority shareholder to sell shares to a majority shareholder, who is obliged to buy the shares of each minority shareholder at his written request, also applies.

20 Arts. 474-476 LoC regulate the following issues pertaining to the special rights of dissenting shareholders: art. 474 - the domain of application of the institute (in respect of which decisions of the assembly taht a shareholder may require the buyback of shares), art. 475 - the procedure and deadlines for the exercise of rights, including the manner of determining the value of shares payable to shareholders, and art. 476 - judicial protection of shareholders rights. All these rules are mandatory.

21 The dissenting shareholder can ask his shares to be purchased, or start proceedings to get adequate compensation for his shares applied in a number of cases. For example, in cases when due to such a decision the change of the status of the company has occurred, having negative impact on the shareholders' voting rights, or the rights to get their dividend, or the rights to have priority in getting company shares, etc. (art. 474 in conjunction with art. 251 pt. 1-4 LoC).
} 
a shareholder of a JSC cannot demand return of shares, nor can at its sole discretion request buyback of shares from the particular JSC, it can be concluded that the provision defining the domain of an application of the rights of dissenting shareholders as an exception to the general rules should be very clear and unambiguous (Veličković, 2017, p. 162). Thus, the relative mandatory rule which prevents certain actions of a JSC shareholder upon his free will creates a deviation. In the respective literature, the special rights of dissenting shareholders are additionally seen as the right of minority shareholders to exit the company, as a way to resolve conflicts between minority and majority shareholders, which may arise during the decision-making process in the company (Veličković, 2017, p. 160). It is therefore clear that a shareholder cannot exit the company if only being unsatisfied with the decision of the state bodies, or any external circumstances (Radović, 2017, p. 53). Anyway, in order for the majority shareholders' decision to be a sufficient reason for exiting of a minority shareholder from the company, the decision needs to be a fundamental one (Radović, 2017, pp. 54-60). ${ }^{22}$ The literature is also critical both towards the difficulties in determination of what is the fair price for shares of a shareholder's exit, as well as to the complicated procedural conditions that a shareholder needs to fulfil to exit a JSC. Therefore, it is considered to be inefficient in practice (Vasiljević \& Radović, 2017, pp. 20-21).

As for this matter, it is also interesting that the provision of art. 477 of the LoC defines that its provisions on rights of dissenting shareholders on the mutatis mutandis principle can be applied to LLCs, unless its articles of association provide otherwise. This provision and its application can cause a lot of practical problems, as LLC founders can anyway exit the company based on arts. 187 and 188 of the LoC. The practice of application of these mandatory rules as the default rules in cases of dissenting LLC founders is therefore strongly criticized in literature with justification (cf. Radović, 2017, pp. 67-69).

In addition, to confirm that in the field of mutual relations of shareholders, there is also a lot of mandatory rules, the provisions of the former Law on Companies ${ }^{23}$ can be cited providing that a shareholder who had personal interest in the legal business of disposing the property of a high value of a JSC had no right to vote at the general meeting of a JSC at making decision on the approval of that legal transaction. Such a view based on the same article of the former Law on Companies was also confirmed in practice at the Serbian courts. ${ }^{24}$

Concerning the compulsory sale of shares, which is regulated by art. 447 of the LoC, when a person buys at least 95\% of the company's shares in relation to the total number in the process of a takeover made by a public offer, he has the right to buy the shares to which the offer relates to, and thus even from those shareholders who did not accept the sale of shares under that offer (dissenting shareholders). The court shall, upon the motion of the dissenting shareholder, prohibit the purchase of shares of the dissenting shareholders only if the conditions are different from those of the public takeover bid. ${ }^{25}$ This is clearly a mandatory rule.

\footnotetext{
22 Thereby, the decisions related to changes of the status or legal form of the company, the time for which the company is founded, the disposition of properties of high value, the amendments of bylaws diminishing the rights of shareholders, delisting of shares or the decisions impacting the rights of shareholders defined in bylaws as the reasons on which the shareholder can reason his exit from the company due to his dissent in the particular matter are deemed findamental (art. 474 LoC).

${ }^{23}$ Art. 34 Law on Companies, Official Gazette of Republic of Serbia no. 125, 2004.

${ }^{24}$ Decision of the Commercial Court of Appeal, PZ 665/10 (03 March 2010) Bilten sudske prakse Privrednih sudova (Practice of Commercial Courts Bulletin) 1/2010, pp. 93-94.

${ }^{25}$ Decision of the Commercial Court of Appeal, PZ 95/10 (12 February 2010) Bilten sudske prakse Privrednih sudova (Practice of Commercial Courts Bulletin) 2-3/2015, p. 238.
} 
All the facts mentioned above confirm that in JSCs, the relations between shareholders and between shareholders and their company are regulated by mandatory rules, while the narrow space for the will of shareholders is mostly filled with relative mandatory rules, allowing them to choose between two options, or to opt for a more strict solution.

\subsection{Rules Related to JSCs in Other Matters}

As to the rules related to the mutual relations of shareholders, and their relations with JSCs, it could not be expected from the situation with default rules to be more liberal with the rules regulating JSCs in other matters. Therefore, the status law matters of JSCs are subject to mandatory rules, with very few exceptions of relative mandatory rules, as opportunities to deviate from the strict provisions of the law.

The mandatory provisions of the LoC in the matter of regulating JSCs are numerous. They define shares, their type and classes, their division, the foundation of JSCs, the articles of incorporation and their content, the minimum equity capital, how to increase or decrease an equity capital, the registration of shares issued, JSC bodies and their nomination, internal and external supervision bodies and procedures, liabilities for keeping and granting an access to the documentation, the change of a legal form and dissolution of JSCs. In certain matters, however, there is still space for deviation from strict the provisions of the LoC, in particular as far as the content of articles of association and bylaws or the choice of bodies when given as options (a board or a director), or the transfer of shares when not limited by the bylaws etc. are concerned.

It should be noted here that the provisions of the LoC which are mandatory can also be used as an instrument to support the limited freedom of contracting. Such exception might be the case of special duties of directors, where the freedom of contracting is essentially manifested in two ways, i.e. in two forms: as the strengthening of the legal regime of special duties and as the mitigation of the same regime. Tightening of the statutory regime of the director's special duties towards the company can be achieved in two ways. Shareholders of the company may expand the scope of the existing directors' duties as provided for by the law. They may also specify other, additional duties that the director would have towards the company that are not provided for by the law (Mihajlović, 2015, p. 162). In addition, mitigation is achieved by limiting the liability of directors in case of breach of a specific duty to the company. This kind of a legal-regimemitigation does not change the rules on duties, but only limits the liability of directors in the event of the breach of a duty (e.g. limitation of the amount of compensation). The legal regulation of special duties, according to certain authors, is necessary only because it is impossible to cover all the rights and obligations of the parties by any contract (cf. Mihajlović, 2015, p. 163).

The articles of association may also designate other persons which are not mentioned by the LoC as persons having special duties towards a company, and thus the legal regime of special duties can be strengthened. The founding act may specify the jobs, manner, or place of their performance that do not constitute breach of the duty in respect to the prohibition of competition. This rule represents the possibility of mitigating the legal regime of special duties towards the company in the Serbian company law, and it can also be seen as a hint of slight transition to contractual understandings (Mihajlović, 2015, p. 169).

The provisions in the JSC law regulating this matter, though mandatory, indicate that the line between mandatory and default provisions is sometimes not absolute and clear, but rather curvy and dispersed, and it varies depending on the subject matter in 
question. The institute of special duties itself requires to be defined by mandatory provisions. And some of the cited reasons support this opinion. However, there are some reasons requiring elasticity and possibility to deviate from the strict mandatory provision.

\section{CONCLUSIONS}

In the Serbian law, the companies were traditionally seen as entities that need to be strongly controlled by the state and after the collapse of communism, though the system evolved towards more liberal views of companies as the subjects of trade, the autonomy of will has cautiously and partly entered into the LoC in the sections related to LLCs and into the matter of relations between its founders. As for JSCs, it can be said that in the LoC, the majority of provisions regulating them are mandatory, and the space for default rules is narrower. It leads more frequently to relative mandatory rules then to default ones.

Why are the rules defining JSCs more stringent, containing substantially more mandatory provisions even in the matter of relations between the founders of the company? Some of the key reasons may come from the fact that on one hand, the shareholders are more depersonalized from their JSC compared to the founders from their LLC, while on the other hand, JSCs are under stronger surveillance than LLCs. The reasons come from: higher minimum equity capital necessary for the foundation of a JSC; the legal nature and easier transferability of JSC shares; a more complex structure of bodies governing JSCs; usually more fixed bonds of founders of LLC than of JSC shareholders; the fact that the most of large companies with high equity capital are formed as JSCs. These differences in characteristics of LLCS and JSCs inspire the legislator to be more cautious when deciding whether to allow more or less space for the free will of shareholders of JSCs to bring decisions on behalf of their companies.

\section{SPECIFIC QUESTIONS AND ANSWERS:}

4.1. How do you determine whether a rule is default or mandatory in the Serbian legal system?

In most cases, it is determined by the wording of the particular provision of the law. It can also be concluded from the general provision defining whether the provisions of the law are regulated by the will of parties or by mandatory rules, if such a provision is included in the law. In addition, it can also be concluded by answering of the following question: is there the need for the protection of common/public interest prevailing in the respective matter, or is it the matter which may be defined by free will of the parties?

The majority of provisions of the company law in Serbia are mandatory, with a few exceptions, where the provisions regulating certain matters are default (e.g. regarding LLCs, the relations between the founders themselves and between founders and an LLC). As for JSCs, the mandatory rules are substantially more frequent than those for LLCs, as shareholders usually have less bonds with the company and its business than the LLC founders do with their company. LLC founders are often close friends or relatives, while shareholders of JSCs often barely know each other, frequently vote by proxies, have no interest in all details of doing business of the company (in the first line, they are usually interested in gaining the profits at the end of the year). 
4.2. Is there a difference between rules affecting third parties and rules having effect only on the founders?

The key difference between the rules affecting third parties and the rules having an effect only on the company founders is that the rules affecting third parties include a requirement that the particular fact is to be registered or put to the insight of the public, i.e. published, in order to have full effect on them. For example, if the decision brought by the founding members is not registered in the public register, i. e. published, a third party can always make an objection that it does not concern him/her. In that sense, third parties are protected by an introduction of subjective deadlines (lasting from the moment a third party has been acquainted with such a decision) to enable them to sue longer time than the founding members in the company, who should be aware of the decisions of the company body from the moment they are made.

However, there are mandatory rules that prevent validity of the decisions and actions of company founders/bodies, unless they are dully registered, thus protecting the third parties. For example, a decision on decrease of equity capital of an LLC not being registered into the public register within three months, becomes null and void. ${ }^{26}$ Or, a decision to register issuance of shares for an increase of the equity capital of a JSC is null and void, unless properly registered within six months period. This provision applies also to LLCs, e. g. to a decision to increase the capital of an LLC, if it is not registered within six months from the date of its adoption with the Business Registers Agency. In such cases it shall be void according to the latest decision of the Serbian Court of Appeal. ${ }^{27}$

Third parties are in general protected by mandatory provisions of the company law, while founders of LLCs in general are free to define their mutual relations with other company founders and company itself autonomously, unless certain mandatory provisions prevent them from doing so.

\subsection{Is there a difference between private/public Ltd. companies?}

No, there is no substantial difference, as far as the status provisions are concerned. These rules are mandatory for both types of a company. However, if private interest of the parties in the particular matter prevails, the rules should be default ones: for example, in the case when the relations between founders of an LLC and their relations with the LLC itself are concerned and the public interest is not jeopardized.

4.4. Has the approach become more liberal/more restrictive over the last years? What are the reasons for such a development (if any)?

The LoC itself, and its provisions, did not go in the direction of being more restrictive. The practice, however, tends to become more restrictive, as far as the control of articles of association (and their changes) on deviations from default rules is concerned. The Business Registers Agency is intervening more than registration courts earlier did, when they were competent for the registration of companies and registration of changes in their articles of association. As a public administrative body, the Business Registers Agency is more active, trying to prevent founders or legal representatives of companies to abuse their rights, offending publicly protected interests. However, this

\footnotetext{
26 This is based on the provision of art. 147 para. 4 LoC.

${ }^{27}$ According to art. 294 LoC and the decision of the Commercial Court of Appeal, PZ 7120/16 (21 February

2018) Bilten sudske prakse Privrednih sudova (Practice of Commercial Courts Bulletin) 1/2019, p. 90.
} 
is good for the sake of the implementation of the LoC, and does not mean that recently, there cannot be observed more liberal approach to its implementation. On the contrary, through the harmonization of Serbian legislation and the practice of its implementation with the EU law in the field of the company law, it has become more liberal.

\subsection{Have corporate governance codes taken over the role of default law lately?}

In the literature, there are views that economic regulation is the area of law that should not be dominated by a zone of mandatory rules - hard law, but a zone of legal authorization (soft law, a zone of contract and freedom of contract). The authors put forward the argument that provisions of the LoC give enough space for implementation of Corporate Governance Codes, which contain recommendations and suggestions. Thereby, the authors are referring to foreign literature on EU law rather than analysing the particular provisions of the Serbian LoC (Vasiljević, 2013, pp. 17-18).

Corporate Governance Codes are not as developed in Serbia as in the EU member states. In Serbia, this topic is of recent date, and with weak support in business practice, especially when it comes to the most widespread categories and forms of companies (LLCs). Additional reason for that is the fact that according to the LoC, only public JSCs have the obligation to adopt code of corporate governance. In the area of corporate governance, Serbia has managed to reach international standards and good regulatory practice, but it still lacks effective enforcement of law. It is prevailingly in hands of Chamber of Commerce and few other institution (such as Belgrade Stock Exchange), which have no substantial impact on the practice of doing business in Serbia.

4.6.If/where company law is mandatory, can the parties find contractual solutions in areas not explicitly regulated by company law?

In Serbia, it cannot be deemed that the whole company law is mandatory, as there are explicit provisions and matters where parties have freedom to define how they will act or regulate their relations. Therefore, they can find contractual solutions in areas of company law which are not explicitly regulated by mandatory company law rules. This in particular relates to the mutual relations between founders of LLCs and their relations with the LLC itself.

\subsection{Can you avoid mandatory rules via shareholders' agreement? Is this done in practice?}

No, the parties can only agree on avoiding the implementation of the default rules, defining that they will act otherwise than foreseen by the default rule of the law. However, they cannot change the mandatory rules of law. The acts brought by founders or company bodies, e. g. decisions/agreements on the foundation of companies, as well as their changes, are to be registered by the Business Registers Agency. If something stipulated in these acts is evaluated to be against the law by agency officers, such acts/agreements will not be registered and must be changed, or they will not have effect.

However, in practice, if the behaviour that is contrary to the mandatory rules is not sanctioned by the public supervising bodies, or is not disputed in front of the courts of justice, this situation may occur.

\section{FINAL NOTE}

As for the mandatory and default rules in the Serbian company law, it can be concluded that this issue has not been sufficiently and adequately discussed, neither in 
literature nor in jurisprudence. However, it can be said that the majority of rules in this matter are mandatory as the consequence of the fact that the company law regulates mainly the status law matters. It can also be said that the rules regulating LLCs are more open to default rules approach, compared to those regulating JSCs. This in particular refers to the matter of mutual relations between the founders of an LLC and between an LLC and its founders. It is actually the only matter which LoC defines as regulated in general by default rules, though there are numerous exceptions here, too.

However, it should not be forgotten that the area between the mandatory and default rules is not sharply delineated. This is confirmed by a number of rules in the status law matter, which are basically mandatory, but also leave space for deviations from strictly defined rules, and thus creating an impression of freedom at least.

\section{BIBLIOGRAPHY:}

Antić, O. (2013). Moral (Etika) u gradjanskom pravu. In D. Marković-Bajalović (Ed.), Harmonizacija gradanskog prava u regionu (pp. 3-55). Istočno Sarajevo:

Univerzitet u Istočnom Sarajevu.

Đurđević, M., \& Pavić, D. (2016). Nekoliko misli o oganičenjima slobode uredjivanja sadržine ugovora u našem savremenom pravu. Pravo i Privreda, 54(7-9), 45-61.

Jevremović-Petrović, T. (2017). Ništavost osnivačkog akta u srpskom pravu. Pravo i Privreda, 55(4-6), 71-94.

Mihajlović, B. (2015). Posebne dužnosti direktora prema društvu sa ograničenom odgovornošću i načelo slobode ugovaranja. Harmonius Journal of Legal and Social Studies in South East Europe, 4(1), 161-172.

Novaković, S. (2018). Komentar zakona o privrednim društvana sa novelama iz 2018. Belgrade: Poslovni biro.

Novičić, S. (2012). Zakon o privrednim društvima i zaštita manjinskih akcionara. In Bilten sudske prakse Privrednih sudova, Privredni savetnik (pp. 115-121). Belgrade: Privredni apelacioni sud.

Radovic, V. (2014). Uslovi za vršenje prava akcionara na postavljanje pitanja. Anali Pravnog Fakulteta u Beogradu, 62(1), 62-83. Retrieved from https://doi.org/ 10.5937/AnaliPFB1401062R

Radović, V. (2010). Informisanje akcionara pre sednice akcionarskog društva. Pravni Život, (3), 117-144.

Radović, V. (2017). Uslovi za ostvarivanje prava nesaglasnih akcionara. Pravo i Privreda, 55(4-6), 49-70.

Stefanović, Z., \& Stanivuk, B. (2012). Komentar zakona o privrednim društvima. Belgrade: Paragraf.

Vasiljević, M. (2006). Komentar zakona o privrednim društvima. Belgrade: Sluzbeni glasnik.

Vasiljević, M. (2013). Država i privreda. Pravo i Privreda, 50(4-6), 13-42.

Vasiljević, M. (2017). Objektivna arbitrabilnost u kompanijskom pravu. In Dvadeset peto savetovanje sudija Privrednih sudova Republike Srbije, radni Materijal II (pp. 291-307). Belgrade: Privredni apelacioni sud.

Vasiljević, M., \& Radović, V. (2017). Teorijske osnove prava nesaglasnih akcionara. Anali Pravnog Fakulteta u Beogradu, 65(3), 7-27.

Veličković, J. (2017). Prava nesaglasnih akcionara - dosadašnja iskustva u praksi. Pravo i Privreda, 55(4-6), 158-178.

Vodinelić, V. (2012). Građansko pravo: Uvod u građansko pravo i opšti deo građanskog prava. Belgrade: Pravni fakultet Univerziteta Union. 
The Civil Code for the Kingdom of Serbia, text as of 11 March 1844.

Serbia, Law on Obligations, Official Journal of the SFRY no. 29/78, 39/85, 45/89 and

57/89, Official Journal FRY no. 31/93 and Official Journal of Serbia and

Montenegro no. 1/2003 - Constitutional Charter and Official Journal of Serbia no. $18 / 2020$.

Serbia, Law on Amendments to the Obligations Act of 1993.

Serbia, Law on Companies, Official Gazette of Republic of Serbia No 36/2011, 99/2011, 83/2014, 5/2015, 44/2018, 95/2018 and 91/2019.

Serbia, Law on Companies, Official Gazette of Republic of Serbia no. 125, 2004.

Serbia, Draft Serbian Civil Code, as of 285 2019. Available at:

https://www.paragraf.rs/nacrti_i_predlozi/280519-prednacrt-gradjanskogzakonika -republike-srbije.html, (last accessed 10 October 2019).

Serbia, Commercial Court of Appeal, PZ 665/10 (03 March 2010) Bilten sudske prakse Privrednih sudova (Practice of Commercial Courts Bulletin) 1/2010.

Serbia, Commercial Court of Appeal, PZ 541/13 (24 January 2013) Bilten sudske prakse Privrednih sudova (Practice of Commercial Courts Bulletin) 4/2013.

Serbia, Commercial Court of Appeal, PZ 95/10 (12 February 2010) Bilten sudske prakse Privrednih sudova (Practice of Commercial Courts Bulletin) 2-3/2015.

Serbia, Commercial Court of Appeal, PZ 7243/13 (20 September 2013) Bilten sudske prakse Privrednih sudova (Practice of Commercial Courts Bulletin) 3/2015.

Serbia, Commercial Court of Appeal, PZ 7120/16 (21 February 2018) Bilten sudske prakse Privrednih sudova (Practice of Commercial Courts Bulletin) 1/2019. 